International Journal of Social Science And Human Research

ISSN(print): 2644-0679, ISSN(online): 2644-0695

Volume 05 Issue 02 February 2022

DOI: 10.47191/ijsshr/v5-i2-43, Impact factor-5.586

Page No: 702-711

\title{
The Impact of Marketing Knowledge on Corporate Brand Image with Mediating Role of Service Marketing Innovation: Evidence from Alexandria Water Co.
}

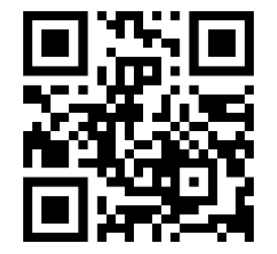

\author{
Islam Ali Ibrahim Mohamed Aboda ${ }^{1}$, Prof. Dr. Alaa El-Gharbawy ${ }^{2}$, Dr. Shaymaa Farid \\ Fawzy $^{3}$, Dr. Mohamed Abdelkader AbdelHamid ${ }^{4}$ \\ ${ }^{1,3,4}$ The Arab Academy for Science and Technology \& Maritime Transport, Alexandria, Egypt \\ ${ }^{2}$ Alexandria University
}

\begin{abstract}
The purpose of this research is to empirically investigate the relationship between Marketing knowledge and corporate brand image with mediating Role of Service marketing innovation in Alexandria Water Co. The objectives of This research are to investigate how Marketing knowledge affect corporate brand image, to examine how Marketing knowledge affect Service marketing innovation, to identify how Service marketing innovation affects corporate brand image, to investigate the mediation role of Service marketing innovation between Marketing knowledge and corporate brand image and to develop a framework for the relationship between Marketing knowledge and corporate brand image in Alexandria Water Co. using structural equation modelling. The methodology will be based on quantitative analysis by using a questionnaire tool to gather required data and structural equation model analyses (SEM) using AMOS software version 25. The main conclusions drawn from this study are the direct effect between marketing knowledge and corporate brand image is statistically significant, the direct effect between marketing knowledge and service marketing innovation is statistically significant, the direct effect between service marketing innovation and corporate brand image is statistically significant. Finally, the study found that the service marketing innovation mediates the relationship between marketing knowledge and marketing knowledge.
\end{abstract}

KEY WORDS: Marketing knowledge, corporate brand image, Service marketing innovation.

\section{INTRODUCTION}

It is undeniable that there is significant knowledge revolution in the field of information specifically through the last few decades which has raised the question of ". Who has the knowledge, owns the creative strength and competitiveness? In addition, modern organizations look at knowledge as the solid base for the concept of innovation, creativity and development. In addition to that, they always seek achieve effectiveness, efficiency and outstanding performance. due to that factor, it is seen that the organizations continuously develop its objectives and products that satisfy the needs and desires of consumers in the target markets based on that, it is necessary for organizations to gain the renewable knowledge and compose an intellectual capital of high value which gives organizations a great competitive and effective advantage in light of knowledge economy and the feedback of the market status. (Abu Fara, 2004)

The phrase, "We live in a service economy," has become ubiquitous. Everywhere in the world, the service sector is growing, such that it accounts for 70 percent or more of the gross domestic product (GDP) in countries such as the USA, UK, France, and Germany, even as the manufacturing sector steadily declines (IMD World Competitiveness Yearbook, 2012).

After decades of development, services have not only dominated our daily lives but also become the most effective driving engine of the world economy, as evidenced by its 53.2\% share of Egypt's gross domestic product (GDP), (World Bank, 2021). The decrease of manufacturing's share of GDP largely reflects lowering prices of goods relative to services (The Economist, 2005).

In a growing pace, many countries started fostering not only innovation in general (Carvalho, et al., 2018), but especially service innovation as a way to face new societal and business challenges (Gallouj, et al., 2015), while companies pursue different innovation strategies to become more competitive in the market (Li, et al., 2018).

Economically, services have been linked to longer-term and more stable sources of revenue, which may protect firms during economic downturns or periods of commoditization (Cusumano, et. al., 2006). Furthermore, service-dominant orientation was found 


\section{The Impact of Marketing Knowledge on Corporate Brand Image with Mediating Role of Service Marketing Innovation: Evidence from Alexandria Water Co.}

to affect positively firms' marketing and technological capabilities which, in turn, affect not only customers' satisfaction but also firms' performance (Ta \& Yang, 2018). The study was guided by the following objectives:

1- $\quad$ To investigate how Marketing knowledge affect corporate brand image

2- $\quad$ To examine how Marketing knowledge affect Service marketing innovation

3- $\quad$ To identify how Service marketing innovation affects corporate brand image

4- $\quad$ To investigate the mediation role of Service marketing innovation between Marketing knowledge and corporate brand image

5- $\quad$ To develop a framework for the relationship between Marketing knowledge and corporate brand image in Alexandria Water Co. using structural equation modelling.

\section{LITERATURE REVIEW}

Marketing knowledge is considered as the independent variable, Service marketing innovation is considered as the mediator variable and corporate brand image is considered as the dependent variable.

\subsection{Marketing Knowledge}

Marketing knowledge has been conceptualized as "market information" which needs to be processed through knowledge acquisition, information distribution, information interpretation and organizational memory (Hanvanich, et al., 2003).

Rossister (2001) defined marketing knowledge as what marketing academics and consultants teach and marketing managers use in formulating marketing plans, and it must exist independently of practitioners' ability to use it, so that marketing knowledge can be documented and shared between individuals.

Marketing knowledge describes organized and structured information regarding markets, customers, competitors and trends. The term marketing knowledge management involves the generation, dissemination and storage of marketing knowledge. The process perspective of knowledge management holds that knowledge generation is the process by which knowledge is acquired. Meantime, knowledge dissemination describes the process by which knowledge from different sources is shared and creates new knowledge or understanding, and knowledge storage is the means by which knowledge is stored for future use (Tsai \& Shih, 2004).

According to Gold, et al, (2001) knowledge management grouped into four processes:

1. Knowledge acquisition which defined as the process by which knowledge is obtained. This process has many terms: generate, seek, and create. The creation of organizational knowledge requires the sharing and dissemination of personal experiences and it is partly based on an organization's absorptive capacity which is the ability to use prior knowledge to recognize the value of new information, and apply it to create a new knowledge and capabilities.

2. Knowledge conversion: is developing a framework for organizing and structuring the obtained knowledge from different sources to make the existing knowledge useful. This process promotes consistent representation, reduces redundancy, improves efficiency, and helps organization to replace knowledge that has become unusual.

3. Knowledge application: is the actual use of the knowledge including effective knowledge storage and knowledge sharing.

4. Knowledge protection: is the process by which knowledge is protected within an organization from illegal or inappropriate use or theft. Protecting knowledge from illegal and inappropriate use is essential for a firm to earn and maintain a competitive advantage

\subsection{Service marketing innovation}

According with Organization for Economic Co-operation and Development OECD \& Eurostat (2005) there exist four types of innovation:

(1) product innovations, referring to significant change in the characteristics of goods and services, meaning new products and improved existing products;

(2) process innovations, referring to significant changes in the methods of product and distribution;

(3) organizational innovations, referring to the implementation of new methods of organizations; and

(4) marketing innovations, referring to all practices of developing new marketing processes, marketing, and selling products or services. Marketing innovation is "the implementation of a new marketing method involving significant changes in product design or packaging, product placement, product promotion or pricing. Marketing innovations are aimed at better addressing customer needs, opening up new markets, or newly positioning a firm's product on the market, with the objective of increasing the firm's sales"

Marketing innovation must be part of a marketing concept and strategy that is significantly different from the original marketing methods. Marketing innovation is based on the understanding that adhering to existing marketing rules alone is not enough to ensure success and competitiveness in crowded markets. (Kotler, 2016) 


\section{The Impact of Marketing Knowledge on Corporate Brand Image with Mediating Role of Service Marketing Innovation: Evidence from Alexandria Water Co.}

Service marketing innovation is a broad concept where it means innovation in all aspects of marketing activity, and therefore it is not limited to a specific field in marketing, such as innovation in the field of service or in the field of advertising only, but includes all other marketing fields, as service marketing innovation affects all activities related to directing the service from the manufacturer to the end user. With the aim of marketing innovation to satisfy consumers better than competitors through ingenuity in identifying and meeting their needs and desires in an accurate manner, and matching them with the capabilities and capabilities of the institution Based on the foregoing, marketing innovation can be defined as "a system that can be learned and practiced, as it does not stop at generating or creating a new idea, but rather than putting this idea into practice, and innovative marketing must successfully operate new ideas in order to be beneficial to the organization". (Lambain, 2008)

This definition includes that innovation in the field of services is also considered a change in procedural processes and commercial transactions, and according to adrian palmer, (2013) innovation in the service relates to the existence of innovation in any activity or scientific related to the service, whether in terms of preparing and delivering the services provided or in terms of developing operations and activities in which services are performed, including services provided with tangible, tangible goods. Here we point out that the new service is defined as: "An additional service provided by the institution, ranging from offering a completely new service that is different from anything else available in the market and simple modifications that are made to an existing service", In terms of marketing, it is preferable to adopt the new concept from the market point of view for the first time, it is new.

According to the above, innovation in services refers to the access to completely new services for the market in which the institution operates, or to modify and improve the existing services in order to reach a distinguished position in the market by responding quickly to the changing needs and desires of customers compared to competitors. In this regard, we mention, for example, that one of the Canadian banks announced the expected time to wait on an illuminated electronic board, so that when the customer enters there is a waiting queue and the board announces to him the expected time to wait in line until he receives the required service, which allowed the bank to satisfy its customers and distinguish this feature from the rest of the competitors. (adrian palmer, 2013)

\subsection{Corporate brand image}

Corporate image denotes a state of mind about an organization that stakeholders hold. Bouchet, (2014) posit that corporate image is what the stakeholders have as a picture in their minds in relation to the way they perceive the organization implying therefore that image is never constant. It keeps on changing depending on the organization activities as well as its performance. This calls for organizations to conduct continuous research on corporate image in order to obtain regular and reliable feedback about their performance. Such feedback would enable organizations to know areas for improvement as well as how to successfully differentiate their positioning in the market. Brand performance relates to how successful a brand is in the market. It provides an evaluation of its strategic success. Literature acknowledges that brand performance acts as a powerful tool for attracting investors, employees as well customers (Coleman, 2004).

Corporate image therefore never remains constant. It keeps on changing depending on an organization's activities, its performance and stakeholders' interpretation. Corporate image can also be defined as the overall impression or the picture that the customers' hold in their minds as a result of the feelings, ideas, attitudes and experiences they have acquired over time through interacting with the organization.

The feelings are stored in the customers memory in terms of either positive or negative meaning and recalled upon when an organization is mentioned. Corporate image also refers to the reception and interpretation of an organization in its surroundings, regarding its identity claims credibility. University image is also defined as all the beliefs individuals might have towards the university (Alves \& Raposo 2010).

Kandampully \& Hu (2007) stated that corporate image consisted of two main components; the first is functional such as the tangible characteristics that can be measured and evaluated easily. The second is emotional such as feelings, attitudes and beliefs the one has towards the organization. These emotional components are consequences from accumulative experiences the customer have with the passage of time with the organization. 
The Impact of Marketing Knowledge on Corporate Brand Image with Mediating Role of Service Marketing Innovation: Evidence from Alexandria Water Co.

\section{CONCEPTUAL FRAMEWORK}

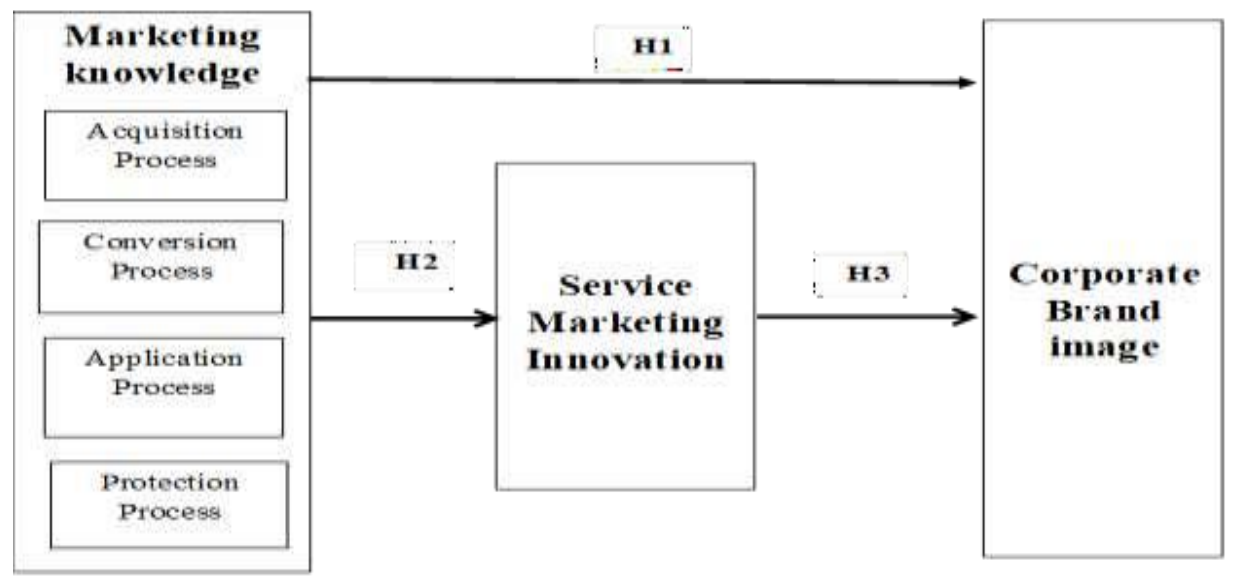

Figure 1-Conceptual Framework

\section{RESEARCH HYPOTHESES}

Based on the conceptual framework, the hypothesized model and reviewing of the related studies and theories, the study hypotheses were formulated as below:

H1: Marketing knowledge has a positive effect on corporate brand image

H2: Marketing knowledge has a positive effect on Service marketing innovation

H3: Service marketing innovation has a positive effect on corporate brand image

H4: Service marketing innovation mediates the relationship between Marketing knowledge and corporate brand image

Research questions could be stated as follows:

1- What is the impact of Marketing knowledge on the corporate brand image ?

2- What is the impact of marketing knowledge on Service marketing innovation?

3- What is the impact of Service marketing innovation on the corporate brand image?

4- What is the impact of marketing knowledge on corporate brand image with Service marketing innovation as a mediating variable?

\section{RESEARCH METHODOLOGY}

For the purpose of this research, the research population refers to Alexandria Water Co. employees. The research questionnaire was administered to eight hundred (800) respondents, 508 questionnaires representing $63.5 \%$ were returned, and 32 questionnaires representing $4 \%$ were incomplete or ineligible or refusals and 292 (36.5\%) were not reached. There were 476 acceptable responses, a response rate $59.5 \%$, which is highly adequate for the nature of this study. In this Research Paper, the Amos 25.0 software package was used to perform the structural equation modelling (SEM) to investigate the inter-relationships between the constructs of the hypothesized model. Hypotheses Testing Following a confirmatory factor analysis, the valuation of the structural model through testing of the hypotheses underlying the research model is conducted.

\section{RESULTS AND FINDINGS}

Composite reliability (CR) is used to measure the reliability of a construct in the measurement model. CR is a more presenting way of overall reliability and it determines the consistency of the construct itself (Hair et al., 2019). CR of Acquisition Process $=0.855$, Conversion Process $=0.874$, Application Process $=0.847$, Protection Process $=0.869$, Service marketing innovation $=0.887$ and corporate brand image $=0.901)$. So, it clearly identified that in measurement model all construct have good reliability.

The average variances extracted (AVE) should always above 0.50 (Hair et al., 2019). The results shows that average variances extracted (AVE) of the particular constructs (Acquisition Process $=0.542$, Conversion Process $=0.581$, Application Process $=0.581$, Protection Process $=0.625$, Service marketing innovation $=0.610$ and corporate brand image $=0.604$ ) are more than 0.500. Overall, these measurement results are satisfactory and suggest that it is appropriate to proceed with the evaluation of the structural model.

Measurement model result: The 6 factor was subjected to CFA using the AMOS software. DF was 362 (it should be more than 0 ), $\square^{2} / \mathrm{DF}$ has a value of 2.734 , that is less than 3.0 (it should be less than or equal 3.0). The RMSEA was .060 (it should be less than 0.08). The TLI index was .925 which is very close to 1.0 (a value of 1.0 indicates perfect fit). The CFI was .933. All indices 
The Impact of Marketing Knowledge on Corporate Brand Image with Mediating Role of Service Marketing Innovation: Evidence from Alexandria Water Co.

are close to a value of 1.0 in CFA, indicating that the measurement models provide good support for the factor structure determined through the CFA

Table 1: Measurement model result

\begin{tabular}{|l|l|l|l|}
\hline Goodness of Fit Measures & Name of index & Model Result & Remark \\
\hline Chi-Square & $\square 2$ & 1762.222 & accepted \\
\hline Degrees of Freedom & DF & 804 & accepted \\
\hline Chi-Square/ Degrees of Freedom & $\square^{2} /$ DF & 2.192 & accepted \\
\hline Comparative Fit' Index & CFI & .911 & accepted \\
\hline Tucker Lewis Index & TLI & .901 & accepted \\
\hline Root Mean' Square Error of Approximation & RMSEA & .054 & accepted \\
\hline
\end{tabular}

Structural model

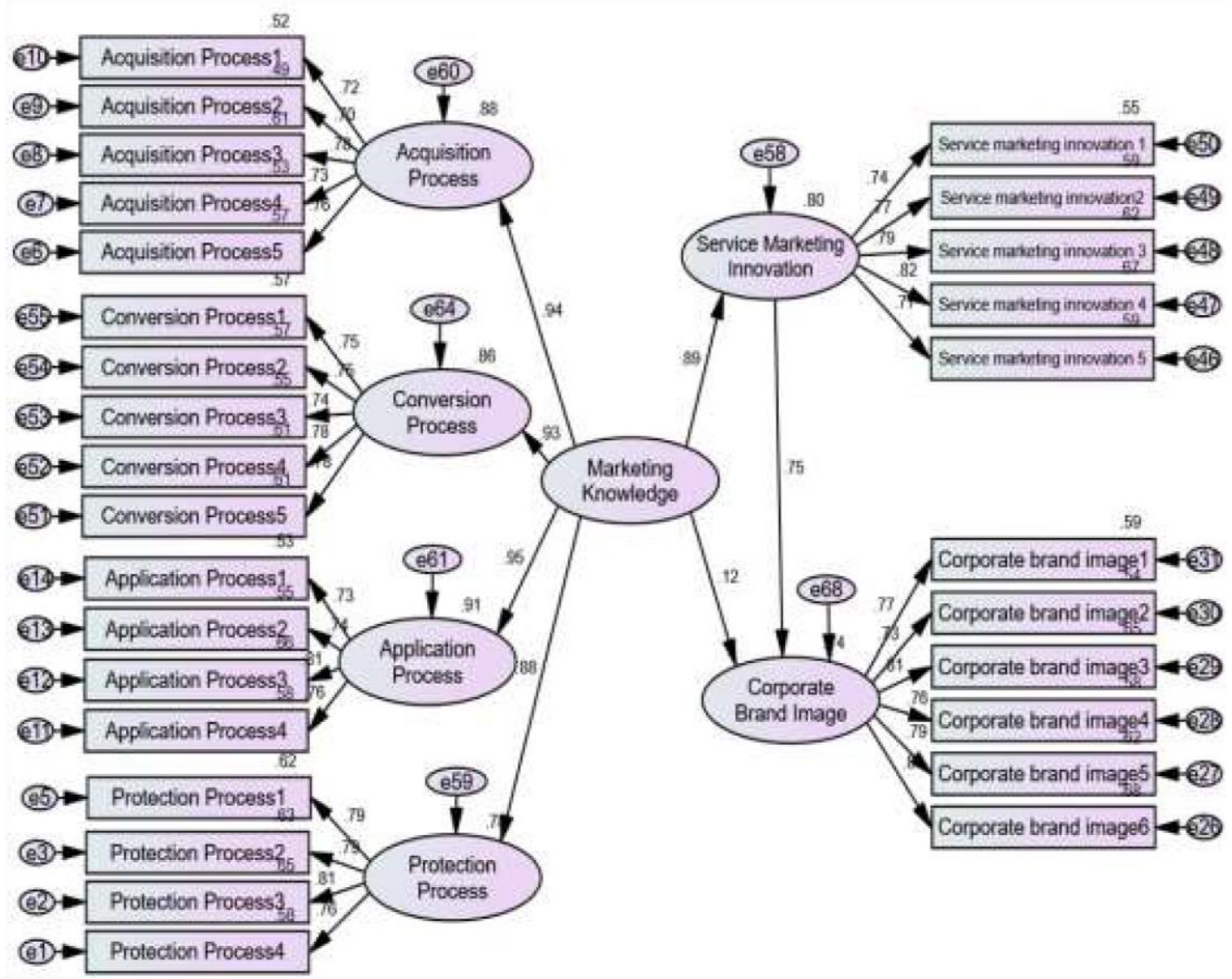

Figure 2. Structural Model (Final Result)

The structural model validity - final Result:

Table (2) provides a structural model (final Result)

Table 2: Structural model - final Result

\begin{tabular}{|l|l|l|l|}
\hline Goodness of Fit Measures & Name of index & Model Result & Remark \\
\hline Chi-Square & $\square 2$ & 989.778 & accepted \\
\hline Degrees of Freedom & DF & 362 & accepted \\
\hline Chi-Square/ Degrees of Freedom & $\square^{2} / \mathrm{DF}$ & 2.734 & accepted \\
\hline Comparative Fit' Index & CFI & .933 & accepted \\
\hline Tucker Lewis Index & TLI & .925 & accepted \\
\hline Root Mean' Square Error of Approximation & RMSEA & .060 & accepted \\
\hline
\end{tabular}




\section{The Impact of Marketing Knowledge on Corporate Brand Image with Mediating Role of Service Marketing Innovation: Evidence from Alexandria Water Co.}

Structural model summary: The results of structural ' model using the AMOS software, shows that DF was 372 (it should be more than 0 ), $\square^{2} / \mathrm{DF}$ has a value of 2.732 , that is less than 2.0 (it should be less than or equal 2.0). The RMSEA was .060 (it should be less than 0.08 ). The TLI index was .925 which is very close to 1.0 (a value of 1.0 indicates perfect fit). The CFI was .931. All indices are close to a value of 1.0 in CFA, indicating that the measurement models provide good support for the factor structure determined through the structural model

\section{FINDING DISCUSSIONS}

The results and hypothesis testing showed that the independent" variable (Marketing knowledge) had a significant positive effect on corporate brand image (dependent" variable corporate brand image) on image in Alexandria Water Co. , Marketing knowledge has a positive effect on corporate brand image in Alexandria Water Co., Marketing knowledge has a positive effect on Service marketing innovation in Alexandria Water Co., Service marketing innovation has a positive effect on corporate brand image in Alexandria Water Co. , Finally, Service marketing innovation mediates the relationship between Marketing knowledge and corporate brand image in Alexandria Water Co. , in details as the follows:

1- $\quad$ First objective, to investigate how Marketing knowledge affect corporate brand image in Alexandria Water Co. and H1: Marketing knowledge has a positive effect on corporate brand image in Alexandria Water Co.

The results indicate that Marketing knowledge has a significant direct relationship with corporate brand image in Alexandria Water Co., Table (5.1). Previous studies by Mamdouh Ziyadat, (2017); Alrubaiee, et. al., (2013); Al-Zayyat and Al-Azzawi) (2008); AlBakri (2006); Jawad (2003) and Lee, et al, (2001) who stated that Marketing knowledge has a significant corporate brand image.

2- $\quad$ Second objective, to examine how Marketing knowledge affect Service marketing innovation in Alexandria Water Co. and H2: Marketing knowledge has a positive effect on Service marketing innovation in Alexandria Water Co.

The results indicate that Marketing knowledge positively influences Service marketing innovation in Alexandria Water Co. this finding was supported by previous literature (Jean, et. al., (2014); Mohaimani and Salehi, (2014); Alrubaiee, et. al., (2013); Veismoradi, et. al., (2013); Genc, et. al., (2013); Yusr, et. al., (2012); Zhou and Bingxin, (2012); Moreira, et. al., (2012); Potocan, (2011); Lin, et. al., (2010); Stone, et. al., (2008); Lee and Sukoco, (2007); Sulaimani (2007); Karmali (2005); Ottesen and Gronhaug, (2004); Tsai and Shih, (2004); Hanvanich, et. al., (2003); Cillo, (2002); Daft (2001); Hanger \& Wheelen (2000); Elsie (1999); Meyer, \& Wit (1998) and Allee (1997)), who stated that Marketing knowledge has a significant effect on Service marketing innovation.

3- Third objective, to identify how Service marketing innovation affects corporate brand image in Alexandria Water Co. and H3: Service marketing innovation has a positive effect on corporate brand image in Alexandria Water Co.

The results indicate that Service marketing innovation has a significant direct relationship with corporate brand image in Alexandria Water Co., That result is consistent with Bin Aly (2017); Suraksha (2016); Tariq Kunduz, (2015); Frank et al. (2015); Lee et al., (2015); Akroush and Akroush, (2004); Alsamydai, et. al., (2010); Han \& Back, (2008); Barnett et al., (2006); Homburg \& Giering, (2001); Hillery et al., (2001); Stern et al., (2001); Hillery et al., (2001) and Agarwal and Prasad, (1999) who stated that Service marketing innovation has a significant effect on corporate brand image.

4- $\quad$ Fourth objective, to investigate the mediation role of Service marketing innovation between Marketing knowledge and corporate brand image in Alexandria Water Co. and H4: Service marketing innovation mediates the relationship between Marketing knowledge and corporate brand image in Alexandria Water Co.

5- $\quad$ Fifth objective, to develop a framework for the relationship between Marketing knowledge and corporate brand image in Alexandria Water Co. using structural equation modelling.

Based on the outcome of the measurement model analysis and the structural model analysis, the research model was re-arranged to conform to the outcome of the two analyses, the final model of research has sought to examine and understand the effects of Marketing knowledge on corporate brand image with mediation role of service marketing innovation in the Egyptian setting in Alexandria Water Co., in particular.

The results indicate that Service marketing innovation mediates the relationship between Marketing knowledge and corporate brand image in Alexandria Water Co., 


\section{The Impact of Marketing Knowledge on Corporate Brand Image with Mediating Role of Service Marketing Innovation: Evidence from Alexandria Water Co.}

\section{RESEARCH CONCLUSION}

The purpose of this research is to empirically investigate the relationship between Marketing knowledge and corporate brand image with mediating Role of Service marketing innovation in Alexandria Water Co. The study was based on a quantitative correlational design where primary sample data were collected from 476 Alexandria Water Co. employees. The results of the regression analysis show that:

1- The direct effect between Marketing knowledge and corporate brand image is statistically significant.

2- The direct effect between Marketing knowledge and Service marketing innovation is statistically significant.

3- The direct effect between Service marketing innovation and corporate brand image is statistically significant.

4- The indirect effect Marketing Knowledge and Corporate brand image through Services Marketing Innovation,

All are indicated significant at 5\% significance level. According to the analysis, the estimated structural model corroborated the four hypotheses, as Marketing Knowledge construct explained $79.9 \%$ of Service marketing innovation variance $\left(\mathrm{R}^{2}=0\right.$. 799), Besides, Marketing Knowledge through Service marketing innovation explained $73.8 \%$ of corporate brand image variance $\left(\mathrm{R}^{2}=0.738\right)$.

\section{RESEARCH LIMITATIONS}

External validity can be defined as referring to the degree to which the results can be generalized to the wider population, cases or situations. (Saunders et al.,2019). Therefore, the researcher cannot assume that research findings generalize to other settings, so the research does not consider:

First, the sample in this study is restricted to one country (Egypt) and only services companies; consequently, the findings need to be interpreted with caution. Although the research context is quite specific, it is believed that the findings are of relevance to other sectors and other countries.

Second, this research was used cross-sectional data to test the association of marketing knowledge and corporate brand image with mediating Role of Service marketing innovation in Alexandria Water Co... Therefor the study provides only a snapshot picture at a single point in time, which means that the research is valid only if external environment variables such as government regulations, economic cycle, competitive environment, etc., are unaffected.

According to O'Neill (2003), there is a need for longitudinal measures for the relationship between Marketing knowledge and corporate brand image, since existing measures for the relationship between Marketing knowledge and corporate brand image with this research is flawed because they do not consider the effects of time on perceptions of stakeholders.

Third, limitation resulted from the collection of data from respondents over a specified time frame using a convenience sampling strategy. The limited time frame for data collection placed a constraint on the variety of respondents who would participate. The use of a convenience sampling approach to gather responses also contributed to possible limits in the variety of respondents who would participate, since responses are gathered by virtue of accessibility of respondents and may not provide a representative sample (Sumaedi et al.,2012).

\section{SUGGESTIONS FOR FUTURE RESEARCH}

Based on the findings from this study, the recommended areas for further research include the following:

First, a study should be conducted using qualitative approach or the mixed approach involving both qualitative and quantitative approaches so as to be able to capture perceptions and expectations of marketing knowledge on corporate brand image.

Second, a longitudinal study should be conducted in order to take care of long-term relationship between Marketing knowledge and corporate brand image with mediating role of service marketing innovation in Alexandria Water Co.

Third, since the sample was limited to only services companies, in future a sample drawn from services and production companies would improve generalizability of the conclusions. This would also help compare relationship between Marketing knowledge and corporate brand image with mediating Role of Service marketing innovation between services and production companies.

\section{REFERENCES}

1) Abu Fara, J. (2004), The relationship between the use of knowledge management and performance, the Fourth Annual Scientific Conference, Knowledge Management in the Arab world, Zitouna University, Jordan.

2) Adrian Palmer, 2013, principles of services marketing, 7th edition, McGraw-Hill

3) Agarwal, R. \& Prasad, J. (1999). Are individual difference germane to the acceptance of new information technologies? Decision Sciences, 30(2), 361-391

4) Akroush, Mamoun Nadim, and Suhair Nadim (2004). New product development. Amman: Wael House. 


\section{The Impact of Marketing Knowledge on Corporate Brand Image with Mediating Role of Service Marketing Innovation: Evidence from Alexandria Water Co.}

5) Al-Bakri, Thamer Yasser, (2006), Marketing knowledge management and its implications for the relationship with the customer to achieve competitive advantage, the Second Scientific Conference, Jordan Applied Science University, College of Economics and Administrative Sciences

6) Allee, V., (1997), “12 Principles of Knowledge Management”, Training \& Development, V (51), Issue (11),

7) Alrubaiee, L., S., Al Mahamid, S., M., Al Adwan, S., Y., \& Al Fadil, H., F. (2013). Investigating the Relationship between Marketing Innovation, Marketing Knowledge andMarketing Performance. 2nd world Conference on Business, Economics and Management. Sentido Zeynep Golf and Spa Resort and Hotel, Belek, Antalya,Turkey.

8) Alsamydai, J., M., Alnawas, A.I., \& Yousif, A.R. (2010). The Impact of Marketing Innovation on Creating Sustainable Competitive Advantage: The Case of Private Commercial Banks in Jordan. Asian Journal of Marketing, 4(3), 113-130

9) Al-Sulaimani, Muhammad. (2007) Marketing innovation and its impact on improving the performance of the institution, Encyclopedia of Islamic Economics and Finance, Mohammed Boudiaf University, Aden, Yemen.

10) Alves, H. \& Raposo, M. (2010). The Influence of University Image on Student Behaviour. International Journal of Educational Management, 24 (1), 73-85.

11) Al-Zayyat, Mamdouh Tayeh and Al-Azzawi, Sami (2008), the effect of customers' market knowledge on brand loyalty for durable (electrical) goods: a field study on heads of households in the city of Amman, The Arab Journal of Management, (1): 191-224. 30

12) Barnett, M. L., Jermier, J. M., \& Lafferty, B. A. (2006). Corporate reputation: The definitional landscape. Corporate reputation review, 9(1), 26-38.

13) Bin Aly, (2017), The role of innovation marketing in improving the mental image (Condor electonic's case), Journal of Financial, Accounting and Administrative Studies Issue 7

14) Bob de Wit and Ron Meyer, (1998)," Strategy: Process, Content, Context: An International Perspective". 2nd Edition, Cengage Learning Business Press.

15) Bouchet, D. (2014). What is"Corporate Image" and "Corporate Identity" - and why do people talk so muchabout it? Retrieved March 15, 2014

16) Carvalho, G. D. G., Carvalho, H. G., Cardoso, H. H. R., \& Gonçalves, A. D. (2018). Assessing a Micro and Small Businesses Innovation Support Programme in Brazil: TheLocal Innovation Agents Programme. Journal of International Development, 30(6), 1064-1068

17) Cillo, P., (2002). Market Learning Capability and Innovation. An Explorative Empirical Study in the Fashion Industry. Ecole Supérieure de Commerce de Paris - EAP, 25-26.

18) Coleman, D.A. (2004). Service brand identity: Definition, measurement, dimensionality and influence on brand performance. (PhD thesis, University of Birmingham, UK)

19) Cusumano, M., Kahl, S., \& Suarez, F. F. (2006). Product, process, and service: a new industry lifecycle model. A research and education initiative at the MIT Sloan School of Management, Working Paper (228).

20) Daft, R., (2001), “Organization: Theory \& Design”, 7th ed., South Western College Publishing,USA.

21) Elsie, L.E., (1999), "Knowledge Flows in Innovation Network: Comparative Analysis of Japanese \& US High Technology Firms", Journal of Knowledge Management, V (3), N (3).

22) Frank, B., Enkawa, T., Schvaneveldt, S. J. \& Torrico, B. H. (2015). Antecedents and consequences of innate willingness to pay for innovations: Understanding motivations and consumer preferences of prospective early adopters. Technological Forecasting and Social Change,99, 252-266.

23) Gallouj, F., Weber, K. M., Stare, M., \& Rubalcaba, L. (2015). The futures of the service economy in Europe: A foresight analysis. Technological Forecasting and Social Change,94, 80-96.

24) Genc, N., Ozbag, G. K., \& Esen, M. (2013). Resource Based View and the Impacts of Marketing and Production Capabilities on Innovation. Journal of Global Strategic Management, 14(1), 24-35.

25) Gold, A. H., Malhotra, A. and Segars, A. H. (2001). Knowledge management: An organizational capabilities perspective. Journal of Management Information Systems. 18(1): 185-214.

26) Hair, J., C.Black, W., J.Babin, B., \& E.Anderson, R. (2019). 'Multivariate Data Analysis' (8th ed.). England: Pearson Prentice.

27) Han, H. \& Back, K. J. (2008). Relationships among image congruence, consumption emotions, and customer loyalty in the lodging industry. Journal of Hospitality \& Tourism Research, 32(4), 467-490.

28) Hanvanich, Sangphet and Droge, Cornelia and Calantone, Roger (2003), "Re conceptualizing the meaning and domain of marketing knowledge, Journal of Knowledge Management, Vol 7 No. 4, pp.124-135.

29) Hillery, M., Nancarrow, B., Griffin, G. \& Syme, G. (2001). Tourist perception of environmental impact. Annals of Tourism Research, 28(4), 853-867. 


\section{The Impact of Marketing Knowledge on Corporate Brand Image with Mediating Role of Service Marketing Innovation: Evidence from Alexandria Water Co.}

30) Homburg, C. \& Giering, A. (2001). Personal characteristics as moderators of the relationship between customer satisfaction and loyalty-an empirical analysis. Psychology \& Marketing, 18(1), 43-66

31) IMD World Competitiveness Yearbook (2012), IMD World Competitiveness Center, Lausanne, Switzerland.

32) Jawad, Adnan Kazem (2003) The Impact of Market Knowledge in Choosing Competitive Strategies and Excellence in Performance / An exploratory study in the durable goods sector in the Jordanian market, The Jordanian Journal of Applied Sciences, (6) Amman.

33) Jean, R. J., Sinkovics, R. R., \& Hiebaum, T. P. (2014). The Effects of Supplier Involvement and Knowledge Protection on Product Innovation in Customer-Supplier Relationships: A Study of Global Automotive Suppliers in China. Journal of Product Innovation Management, 31(1), 98113.

34) Kandampully, J.; and Hu, H.H., (2007),"Do hoteliers need to manage image to retain loyal customers?", International Journal of Contemporary Hospitality Management, Vol. 19, No. 6, pp. 435 - 443.

35) Karmali, Sultan (2005). Knowledge management: an applied approach. Amman: Eligibility for publication.

36) Kotler, P., \& Keller, K. L. (2016). Marketing Management, 15th Edition, England: Pearson Education Limited.

37) Lambain, J, (2008), "Strategic marketing", France: Edi science international, , p281

38) Lee, ChingChyi, Jie Yang, Ya Liming, (2001) The Knowledge Value of Customers and Employees in Product Quality,Journal of management development, vol.20, issu 8, PP:691-706.

39) Lee, L. T. \& Sukoco, B. M., (2007), The Effects of Entrepreneurial Orientation and Knowledge Management Capability on Organizational Effectiveness in Taiwan, Vol. 24 No.3

40) Li, M., Jian, Z. Q., Li, L., \& Yeung, T. K. H. (2018). Effects of organisational learning on service innovation performance: the mediating effect of supply chain collaboration and the moderating role of interpersonal trust. International Journal of Services Technology and Management, 24(1-3), 43-61.

41) Lin, R. J., Chen, R. H., \& Kuan-Shun Chiu, K. (2010). Customer relationship management and innovation capability: an empirical study. Industrial Management \& DataSystems,110(1),111133.

42) Mamdouh Ziyadat, (2017), "The role of marketing knowledge in building a mental image and its impact on enhancing customer satisfaction Clients / A field study on the clients of Islamic banks operating in Jordan", The Jordanian Journal of Applied Sciences, "The Human Sciences Series," Volume 19, Issue 1,

43) Mohaimani, M., \& Salehi, S. A. S. (2014). Investigating the Meditative Role of Innovation Orientation and Marketing Capabilities between the Competitive Intensity and Customer Relationship Performance. Asian Journal of Business Management, 6(1), 25-33

44) Moreira, J., Silva, M. J., Simoes, J. \& Sousa,G. (2012). Marketing Innovation: Study of Determinants of Innovation in the Design and Packaging of Goods and Services Application to Portuguese Firms. Contemporary Management Research, 8 (2), 117-129

45) OECD/Eurostat (2005). Oslo manual. 3rd ed. Paris: OECD. Available from: http://www.oecd.org/.

46) O'Neill, M. (2003). The influence of time on student perceptions of service quality: the need for longitudinal measures. Journal of Educational Administration, 41(3), 310-325.

47) Ottesen, G.G. \& Grønhaug, K. (2004). Barriers to Practical Use of Academic Marketing Knowledge. Marketing Intelligence \& Planning, 22(5), 520-530

48) Potocan, V. (2011). Marketing Capabilities for Innovation- Based Competitive Advantage in The Slovenian Market. Innovative Issues and Approaches in Social Sciences, 6(1), 118-13.

49) Rossister, R.J. (2001). What Is Marketing Knowledge? Stage I: forms of marketing knowledge. Marketing Theory, 1(1), 9-26.

50) Saunders Mark, Lewis Philip, Thornhill Adrian, (2019), Research Methods for Business Students,

51) Pearson Education Limited

52) Stern, B., Zinkhan, G. M. \& Jaju, A. (2001). Marketing images Construct definition, measurement issues, and theory development. Marketing Theory, 1(2), 201-224.

53) Stone, A., Rose, S., Lal, B., \& Shipp, S. (2008). Measuring Innovation and Intangibles: A Business Perspective. Institute for Defense Analysis, Science and Technology Policy Institute, Washington, DC

54) Sumaedi, S., Bakti, I.G.M.Y. and Metasari, N. (2012) 'The effect of students' perceived service quality and perceived price on student satisfaction', Management Science and Engineering, Vol. 5, No. 1, pp.88-97 .

55) Suraksha G. N. (2016) Marketing innovation: A consequence of competitiveness. Journal of Business Research, 69 (12), $5671-5681$

56) Tariq Kunduz, 2015,"The Effectiveness of Marketing Innovation in Improving Banking Service",

57) Journal of Innovation and Marketing, Journal 1, Issue 1, 2, pp. 296-271

58) The Economist (2005), "Industrial metamorphosis", The Economist, 29 September 
The Impact of Marketing Knowledge on Corporate Brand Image with Mediating Role of Service Marketing Innovation: Evidence from Alexandria Water Co.

59) Tsai, M.T. \& Shih, C.M. (2004). The Impact of Marketing Knowledge among Managers on Marketing Capabilities and Business Performance. International Journal of Management ,21(4), 524-530.

60) Veismoradi, A., Akbari, P., \& Mohammadi, A. (2013). The study relationship between marketing knowledge management assets and capabilities and banking industry performance of Iran (Case study: Saderat Bank of West Country). International Journal of Management and Humanity Sciences, 2(1), 25-34.

61) Wheelen, T.L., \& Hanger, J.D., (, 2000), “Strategic Management \& Business Policy”, Addison Wesley Langman. 14.

62) Yusr, M.M., Othman, A.R., \& Mokhtar, S.S. (2012). Assessing the Mediating Role of Marketing Capability in The Relationship Between TQM Practices and Innovation Performance Dynamic Capabilities Approach. International Journal of Business and Social Science, 3(23), 165-176.

63) Zhou, K.Z. \& Bingxin, C. (2012). How Knowledge Affects Radical Innovation: Knowledge Base, Market Knowledge Acquisition, and Internal Knowledge Sharing. Strategic Management Journal, 33(9), 1090-1102 